\title{
ASSESSMENT OF AN EAST-WEST PHENOTYPIC VARIATION IN BODY HEIGHT, BODY FORM AND BODY MASS AMONG PREHISTORIC HUNTER-GATHERERS OF PATAGONIA AND TIERRA DEL FUEGO, CHILE
}

\author{
EVALUACIÓN DE LA VARIACIÓN FENOTÍPICA DEL PESO, LA FORMA \\ $Y$ LA MASA CORPORAL EN GRUPOS CAZADORES-RECOLECTORES \\ PREHISTÓRICOS DE PATAGONIA Y TIERRA DEL FUEGO, CHILE
}

\author{
Marta Alfonso-Durruty ${ }^{1 * 2}$, Bretton T. Giles ${ }^{1,3}$, Manuel San Román ${ }^{4}$, and Flavia Morello ${ }^{4}$
}

\begin{abstract}
Fuego-Patagonia's marine and terrestrial groups were historically described as phenotypically distinct but, studies of these phenotypic differences have yet to be conducted. This study evaluates phenotypic variation in Fuego-Patagonia. Phenotypic disparities result from extrinsic and intrinsic factors and therefore can reveal differences in both long and short term adaptations as well as genetic differences. Fifty-one adults were assessed. A total of six post-cranial measurements were included: maximum length of the humerus (MHL); maximum length of the radius (MRL); Bicondylar length of the femur (BFL); Maximum length of the tibia (MTL); bi-iliac breadth (BIB), and; antero-posterior diameter of the femoral head (FHD). Brachial index, crural index, body mass, body mass index and stature were then calculated. In general, terrestrial individuals had longer lower limb bones and were the tallest and heaviest. Marine individuals had the shortest bones and were shorter and lighter. Mixed-economy individuals showed mostly intermediate values. The trends are more marked in males than in females. The results suggests the presence of an east-to-west phenotypic gradient in the region that may have resulted from intrinsic and/or extrinsic differences between the groups. But, the sample size of this study is small, and thus the results should be cautiously considered.
\end{abstract}

Key words: Phenotypic variation, Fuego-Patagonia, human colonization.

Históricamente grupos marinos y terrestres de Fuego-Patagonia fueron descritos como fenotípicamente distintos. Este estudio examina la presencia de esta variación fenotípica, la cual de existir, podría ser resultado de factores extrínsecos, como son los procesos adaptativos de corto o largo plazo e intrínsecos como son los factores genéticos. La muestra se compone de 51 individuos adultos. Se incluyeron seis mediciones post-craneales: longitud máxima del húmero (MHL); longitud máxima del radio (MRL); longitud bicondilar del fémur (BFL); longitud máxima de la tibia (MTL); ancho bi-ilíaco (BIB), y; diámetro antero-posterior de la cabeza femoral (FHD). También se calcularon el índice braquial, el crural, la masa corporal, el índice de masa y la estatura. En general, los individuos terrestres tenían huesos de la extremidad inferior más largos y eran por ende más altos y pesados. Los individuos marinos tenían los huesos más cortos y eran más bajos y livianos. Los individuos de economía mixta mostraron valores intermedios. Esto sugiere la presencia de una gradiente fenotípica de este a oeste, que es más marcada en individuos masculinos, y que puede haber resultado de diferencias extrínsecas y/o intrínsecas. Sin embargo, dado el tamaño pequeño de la muestra, estos resultados deben ser considerados con cautela.

Palabras claves: variación fenotípica, Fuego-Patagonia, colonización humana.

Fuego-Patagonia $\left(47^{\circ}-56^{\circ} \mathrm{S}\right)$ has two contrasting environmental zones characterized by phytogeographic fringes that follow a northwest-southeast pattern. The Patagonian archipelago, to the western slopes of the Andes including the intermountain areas, is an environment of low temperatures $\left(-3-10^{\circ} \mathrm{C}\right.$ annual temperature range) and high humidity $(\sim 5,000 \mathrm{~mm}$ precipitation per year) that supports two vegetation assemblages, tundra and evergreen forests, found in association with contrasting topographic conditions and a labyrinth of channels, fjords and islands. The second geographic area, a semiarid region with low precipitation and two phytogeographic fringes of deciduous forests and steppes, extends from the eastern slopes of the Andes to the shores of the Atlantic, mainly across pampas and grassland plains. Protected from the winds that come from the Pacific Ocean, the area presents relatively low humidity (200-400 $\mathrm{mm}$ precipitation per year), and overall low temperatures $\left(\sim-3.2-11^{\circ} \mathrm{C}\right.$ annual temperature range. Figure 1; Moore 1983; Pisano 1977).

\footnotetext{
Departamento de Antropología Universidad Alberto Hurtado, Santiago, Chile. *Corresponding author: malfonso@uahurtado.cl 2 Sociology, Anthropology, and Social Worl Department, Kansas State University Manhattan, Kansas, USA.

Center for Environmental Management of Military Lands. Colorado State University, Fort Riley, Kansas, USA. brettongiles@yahoo.com

4 Centro de Estudios del Hombre Austral, Instituto de la Patagonia, Universidad de Magallanes, Punta Arenas, Chile.

msanromanbontes@gmail.com; flavia.morello@umag.cl
}

Recibido: junio 2017. Aceptado: noviembre 2017.

http://dx.doi.org/10.4067/S0717-73562017005000112. Publicado en línea: 11-diciembre-2017. 


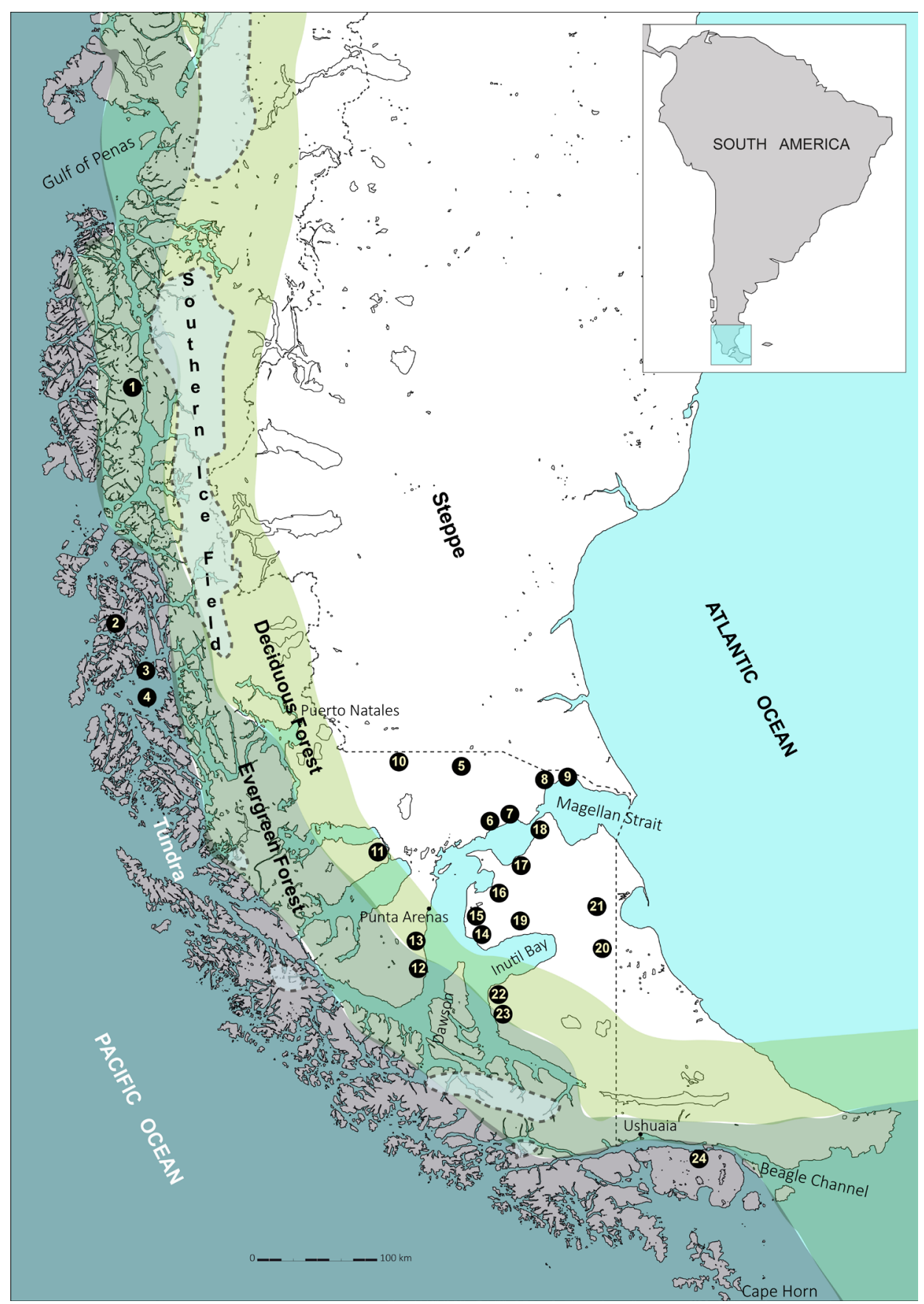

Figure 1. Phytogeographic regions of Fuego Patagonia. Sites where the prehistoric samples were found: (1) Yekchal; (2) Isla Madre de Dios; (3) Caverna 1 Pto. Natales*; (4) Caverna 3 Pto. Natales*; (5) Cerro Johny; (6) Bahía Santiago-4; (7) San Gregorio-12; (8) Posesión (Olimpia); (9) Daniel; (10) Juniaike 6; (11) Ponsonby; (12) Pta. Santa Ana-1 and Rey Felipe; (13) Punta Santa María; (14) Bahía Chilota; (15) Estancia Silvana María, Laguna Verde and Lengua de Vaca; (16) Bahía Gente Grande; (17) Bahía Felipe; (18) Faro Méndez 1ª Angostura; (19) Myren-1; (20) Tres Arroyos-1; (21) Laguna Flamenco; (22) Cabo Nose; (23) Punta Cameron (Timaukel); (24) Lauta-2. * Imprecise location.

Regiones fitogeográficas de Fuego-Patagonia. Ubicación de los sitios arqueológicos de donde provienen los individuos prehistóricos considerados en este estudio: (1) Yekchal; (2) Isla Madre de Dios; (3) Caverna 1 Pto. Natales*; (4) Caverna 3 Pto. Natales*; (5) Cerro Johny; (6) Bahía Santiago-4; (7) San Gregorio-12; (8) Posesión (Olimpia); (9) Daniel; (10) Juniaike 6; (11) Ponsonby; (12) Pta. Santa Ana-1 and Rey Felipe; (13) Punta Santa María; (14) Bahía Chilota; (15) Estancia Silvana María, Laguna Verde and Lengua de Vaca; (16) Bahía Gente Grande; (17) Bahía Felipe; (18) Faro Méndez $1^{a}$ Angostura; (19) Myren-1; (20) Tres Arroyos-1; (21) Laguna Flamenco; (22) Cabo Nose; (23) Punta Cameron (Timaukel); (24) Lauta-2. * Ubicación exacta es desconocida. 
The earliest human occupations in the region are dated to the Late Pleistocene (ca. 12,500 cal. yrs. BP) and correspond to terrestrial hunter-gatherers, who lived on the pampas (eastern slopes), and exploited modern and extinct fauna (Bird 1993, 1946; Borrero 2002; Borrero and Martin 2012; Martin et al. 2015; Massone 1989, 2004; McCulloch and Morello 2005). After the Last Glacial Maximum, a gradual rise in sea levels resulted in a shoreline modification (12,000-8,000 BP) that led to the establishment of modern marine environments (Borrero 1999; McCulloch et al. 2005; Morello et al. 2012). By 7,000 cal. yrs. BP (Middle Holocene), the earliest evidence of marine hunter-gatherers appeared. These groups practiced sea navigation and had a highly specialized tool kit that featured detachable harpoons, spatulas and wedges made from cetacean bones, as well as rock cobble fishing weight (Englefield tradition; Orquera et al. 2011; San Román 2014). Thus, two divergent adaptations, canoe-marine and pedestrianterrestrial hunter gatherers, were already established by the Middle Holocene. In addition to these two adaptations, archaeological sites reveal the presence of groups with mixed cultural and economic assemblages in fjords, channels, interior seas and forest-steppe ecotones (Borrero 2002; Laming-Emperaire et al. 1972; Lanata 2002; Legoupil 2003; Morello et al. 2012; Orquera et al., 2011; Ortiz-Troncoso 1975; San Román 2014). By the Late Holocene period $(<4,000$ cal. yrs. BP), and specifically in the last two millennia, a demic expansion without demographic pressure, spatial saturation or significant economic changes, led to an important increase in the number of sites for both marine and terrestrial groups (Borrero 1989; Borrero et al. 2011; Morello et al. 2012).

In historic times $\left(19^{\text {th }}\right.$ and $20^{\text {th }}$ centuries $)$, European and Criollo writers characterized Fuego-Patagonia ethnic groups by economic specialization (marine and terrestrial) and geographic location. Interestingly, their descriptions identify these groups as phenotypically distinct. While terrestrial groups were portrayed as tall and robust, and referred to as the "giant Patagons", marine groups were characterized as short and gracile, and were generically identified as Fueguians (Emperaire 2002; Gusinde 1961, 1980, 1982; Martinic 1995; Orquera and Piana 1999).

The variability of body size and shape in modern human populations is high, with an estimated range of variation in weight (mass) of around $50 \%$ or more within each sex, and a 10\% variation in height (Ruff 1994, 2002). Thus, bioarchaeological estimates of stature and body mass from skeletal dimensions are relevant, as they allow us to address questions regarding adaptation and population history. Therefore, the analysis of body shape and proportions in skeletal remains is informative at several levels. In modern humans, body shape and body proportions show some correspondence with ecogeographic regions due to their role in the efficient dissipation or retention of heat as expected based on the Bergmann's and Allen's rules (Allen 1877; Bergmann 1847; Mayr 1956). Body size and proportions are also affected by factors such as socio-economic status, psychosocial stress, physical activity, climate, altitude and seasonality. All these factors, however, ultimately hinge on nutrient availability, which is in turn dependent on disease and nutrition (Bogin 1999, 2001; Eveleth and Tanner 1991; Frisancho 2007; Lee et al. 2014; Lejarraga 2002; Meinhardt et al. 2017; Norgan 2002; Pomeroy et al. 2012, 2015; Schell and Knutsen 2002; Specker and Schoenau 2005; Stinson 2000; Tanner 1990; Ulijaszek et al. 1998). In addition to external factors, genetic differences will affect growth and its ultimate outcomes (e.g. stature and mass among others) as the genotype determines the reaction norms or developmental limits of the organism (Charnov 1993; Livshits et al. 2002; Metcalfe and Monaghan 2001; Schell and Magnus 2007).

Thus, while some studies indicate that stature and long-limb dimensions are correlated with ecogeographic regions as a result of thermal selection (Betti et al. 2012; Holliday and Hilton 2010), others show that postcranial morphology can be retained from ancestral groups for several millennia thus informing about processes related to population history (Holliday 1997; Holliday and Falsetti 1995). Therefore, studies of postcranial morphology can inform us about colonizing processes (Auerbach 2012), as well as environmental adaptation, and life-styles (Hermanussen et al. 2015; Higgins and Ruff 2011). Thus, the interpretation of morphological differences between groups must consider all these factors.

\section{Hypotheses}

The goal of this study is to assess whether or not marine, mixed-economy and terrestrial groups from Fuego-Patagonia, were phenotypically distinct from one another in terms of height, weight and limb proportions. To assess this, we propose the following hypotheses: (1) no phenotypic differences in stature, limb proportions, and/or body mass between these terrestrial, mixed-economy, and/or marine groups existed, or (2) phenotypic differences in stature, limb proportions, and/or body mass between terrestrial, mixed-economy, and/or marine groups did exist, and individuals of mixed economy exhibited an intermediate morphological pattern in relation to marine and terrestrial groups. In Patagonia, north-tosouth latitudinal phenotypic gradients, likely related to climate differences, have been identified (Béguelin and Barrientos 2006). To date, however, east-to west 
phenotypic differences have yet to be explored. In particular, regional-level analyses of possible phenotypic differences are especially needed considering that early European characterizations have become perpetuated (Borrero et al. 2011). Accordingly, this study assesses the linear dimensions, height, limb indices, and body mass of prehistoric and historic marine, mixed-economy and terrestrial hunter-gatherers from Southern Patagonia and Tierra del Fuego, Chile.

\section{Materials and Methods}

Fifty-one adult individuals were included in this study. Thirty of them come from prehistoric sites dated between ca. 7,000-1,000 cal. yrs. BP (Figure 1). Their inclusion in this study was based on their degree of conservation and the well documented nature of the archaeological sites where they were found. Prehistoric individuals were classified as marine, terrestrial, or mixed-economy hunter-gatherers, based on their archaeological and geographic context, as well as dietary (isotope) information when available (Alfonso-Durruty et al. 2015). Data from the remaining 21 individuals was obtained from the Goldman Osteometric Data Set (Auerbach 2014; Auerbach and Ruff 2004). The latter are modern individuals whose remains were collected from historic cemeteries, and their classification as marine or terrestrial hunter-gatherers (since there are no mixed-economy groups documented in the ethnographic record) was based on their ethnic affiliation as described in the Goldman Osteometric Data Set (Auerbach 2014; Auerbach and Ruff 2004).

Age and sex were estimated for all prehistoric individuals following standard anthroposcopic methods based on markers visible on the pelvis and the skull. Traits considered for sex estimation included the: ventral arc, subpubic concavity, ischiopubic ramus ridge, greater sciatic notch, nuchal crest, mastoid processes, supraorbital margin, supraorbital ridge and mental eminence. Adult age estimation was based on ectocranial suture closure (lateral-anterior sites) as well as changes in the pubic symphysis and auricular surface (Acsádi and Nemeskéri 1979; Brooks and Suchey 1990; Buikstra and Ubelaker 1994; Katz and Suchey 1986; Lovejoy et al. 1985; Meindl and Lovejoy 1985, 1989; Phenice 1969; White et al. 2012). When the remains were too incomplete or lacked sufficient osteological markers to estimate age and/or sex, the individuals were deemed of indeterminate sex, and/ or of indeterminate adult age. Information regarding age and sex estimates for the modern individuals included in this study (Goldman Osteometric Data Set) can be found in Auerbach and Ruff $(2004,2006)$ and in Auerbach (2014). The methods used by these authors are the same, or similar, to the ones we applied in this study to the prehistoric remains.

Six dimensions were measured (in $\mathrm{mm}$ ) in each skeleton: (1) Maximum length of the humerus (MHL);
(2) Maximum length of the radius (MRL); (3) Bicondylar length of the femur (BFL); (4) Maximum length of the tibia (MTL); (5) Bi-iliac breadth (BIB), and; (6) Anteroposterior diameter of the femoral head (FHD; Auerbach and Ruff 2004, 2010; Buikstra and Ubelaker 1994). Measurements 1-5 were taken with a portable osteometric board (Paleotech). The sixth measurement (FHD) was taken with a digital Mitutoyo sliding caliper $(200 \mathrm{~mm})$. The bi-iliac breath (BIB) was measured in the portable osteometric board after the ossa-coxae were articulated with the sacrum and held in anatomical position (Ruff 2000). In order to limit the effects of bilateral directional asymmetry, both left and right skeletal elements were measured (when available) and then averaged. The instruments and methods used to measure historic individuals (in the Goldman Osteometric Data Set) are identical (Auerbach 2014; Auerbach and Ruff 2004).

Long bone measurements were used to calculate intralimb indices. The brachial index was calculated as the proportion of the radial maximum length in relation to the humeral maximum length times one-hundred. The crural index was estimated as the proportion of the tibial maximum length to the femoral bicondylar length times one-hundred (Auerbach 2012; Davenport 1933).

Stature estimates were derived from the input of lower limb long bone lengths (femur, tibia, and femur plus tibia) into a series of selected formulae (see below). The mathematical approach to stature estimation is based on the extrapolation of living stature based on the application of ratios or regression formulae. The equations are developed based on specific populations that have characteristic body and intralimb proportions. Thus, population specific stature formulae are necessary, and a careful selection of the most appropriate formulae should be based on proportions, such as the crural index, as well as geographic region and genetic origins (Auerbach and Ruff 2010).

To date, few equations have been developed for stature estimation in the Americas. In particular, Auerbach and Ruff (2010) developed formulae for three different North American regions, whereas Angel and Cisneros (2004) developed formulae for groups from Central America. Among the few formulae developed for Native South American groups, are the ones for Andean peoples (Pomeroy and Stock 2012), and the population-specific formula for Patagonian males (Béguelin 2011). In this study, selection of the formulae applied considered the fact that there are significant inter-population differences in body proportions (Ruff 2002). Following Auerbach and Ruff's $(2010,2004)$ recommendations, the average crural index for males and females in this study was compared to other reference New World populations before selecting the formulae to calculate stature (Auerbach and Ruff 2010; Pomeroy and Stock 2012). All selected formulae used the femur, tibia and femur plus tibia dimensions. Formulae that used lower limb long bone dimensions were privileged as these bones contribute directly to an 
individual's stature.

Body mass was calculated (in $\mathrm{kg}$ ) using both the biomechanical (FHD) and morphometric (BIB) methods. For the biomechanical methods the formulae developed by Ruff et al. (1991), McHenry (1992), and Grine et al. (1995) were applied and then averaged as recommended by Auerbach and Ruff (2004). The morphometric method was also applied as it is considered more reliable than the biomechanical one and because it allowed us to estimate body mass in individuals where the femoral heads were not available (Auerbach and Ruff 2004; Ruff et al. 1997). The application of the morphometric body mass estimation method requires two variables: bi-iliac breadth and stature. For the stature variable the mean from all the stature estimates obtained in each individual was applied. Morphometric calculations are sex-specific and no formulae are available for individuals of undetermined sex. Thus, we were not able to estimate the body mass of individuals of undetermined sex with this method. In order to assess whether the possible differences in body mass where due to differences in stature or whether they represented differences in body mass index, the later (BMI; body mass index) was calculated as the result of the average body mass estimated with the biomechanical and morphometric methods divided by the squared average (in meters) for all stature estimates (Ruff et al. 1997).

Statistical analyses were conducted in SPSS21® (IBM Corp. 2012). All skeletal dimensions estimates were tested for normality with Kolmogorov-Smirnoff tests in order to assess whether parametric or nonparametric analyses should be applied. In both males and females small sample sizes for all dimensions, ratios, body mass estimates and body mass index prevented the assessment of normality in one or two of the groups. Thus, non-parametric statistics were applied to assess differences between the groups. Given this limitation, between groups comparisons were carried out with Kruskal-Wallis tests followed by post-hoc Mann Whitney tests when the results were significant. When only two of the three groups (marine, terrestrial or mixed-economy) had a sufficiently large number of individuals for statistical analyses, the comparisons were conducted with Mann-Withney U tests. No statistical analyses of stature estimates are included as they would repeat the analyses of the bone dimensions. However, stature was estimated for all groups to assess whether these groups looked different.

\section{Results}

The composition of the sample by sex, and economic specialization can be found in Table 1. Economic ascription corresponded mostly to terrestrial $(n=14)$ or marine strategies $(n=30)$. Only a few individuals were ascribed to the mixed economy group $(n=7)$, and all were prehistoric. Anthroposcopic analyses of the remains revealed that most individuals were males. Although females were identified in all groups (marine, terrestrial and mixed-economy), their numbers are low, except for the marine segment of the sample (Table 1). Only two individuals of indeterminate sex were identified. One of them corresponds to a terrestrial, and the other one to a marine hunter-gatherer. Other studies have also identified unbalanced sex distribution in Fueguian and Patagonian samples (Bernal et al. 2006). While a high degree of cranial robusticity in Patagonian samples, which could bias sex estimation, has been identified (Bernal et al. 2006), genetic analyses of human remains in Fuego-Patagonia show a high degree of agreement between morphological and genetic estimates of assessment of sex (AlfonsoDurruty unpublished data).

Descriptive statistics for all measurements and indices by sex and economic specialization are shown in Table 1 . Four of the six dimensions considered in this study (MRL, BFL, MTL and FHD) were shown to be larger among terrestrial males than in mixed-economy or marine males. Exceptions to this trend were found in the MHL and BIB, which measurements where highest among mixed-economy males. However, the BIB was only available for one mixed-economy male, and thus, this result must be cautiously considered. Mixed-economy males showed intermediate values, meaning lower than terrestrial but higher than marine males, in three out of the six measurements (BFL, MTL, and FHD). Mixedeconomy males had the shortest MRL of the three groups. Thus, with the exception of the MRL, for which they had the second highest dimensions among males, most measurements taken in marine males were the lowest of the three groups (Table 1). No statistically significant difference between the groups were identified in MHL $\left(X^{2}=4.88, p>05\right)$, MRL $\left(X^{2}=3.89, p>05\right)$, or MTL $\left(\mathrm{X}^{2}=4.29, \mathrm{p}>.05\right)$. A statistically significant difference in BIB $(Z=-2.42, p<.05)$ was identified, indicating that this dimension was larger among terrestrial males, in relation to marine males (Table 1). Statistically significant differences were also identified in FHD $\left(\mathrm{X}^{2}=6.54\right.$, $\mathrm{p}<.05)$. Post-hoc analyses showed significant differences between terrestrial and marine males $(\mathrm{Z}=-2.50, \mathrm{p}<0.5)$ where the former had overall larger femoral head diameters. Other post-hoc between group comparisons for FHD were not statistically significant. Comparisons of BFL were also significant $\left(\mathrm{X}^{2}=9.67, \mathrm{p}<.05\right)$. Post-hoc tests reveal a significant difference in BFL between terrestrial and marine hunter-gatherers, where the former had significantly larger measurements $(\mathrm{Z}=-2.97, \mathrm{p}<.01)$. Likewise, comparisons between terrestrial and mixedeconomy hunter-gatherers were shown to be significant for BFL $(Z=-2.05, p<.05)$, due to the larger femoral length of the terrestrial males. However, post-hoc comparisons for BFL did not reveal a significant difference between marine and mixed-economy males ( $\mathrm{p}>05$ ). 
Table 1. Sample composition and descriptive statistics for all dimensions ( $\mathrm{mm}$ ) and indexes.

Composición de la muestra y resultados descriptivos para todas las dimensiones $(\mathrm{mm})$ e índices.

\begin{tabular}{|c|c|c|c|c|c|c|c|c|c|c|}
\hline \multirow{3}{*}{$\begin{array}{c}\text { Economic } \\
\text { Specialization }\end{array}$} & \multirow[t]{3}{*}{ icteristics } & \multirow{3}{*}{$\begin{array}{l}\text { Sample } \\
\text { Size }\end{array}$} & \multicolumn{6}{|c|}{ Mean Dimensions } & \multicolumn{2}{|c|}{ Mean Indices } \\
\hline & & & $\begin{array}{c}\text { Mx. } \\
\text { Humeral } \\
\text { Length } \\
\text { (MHL) }\end{array}$ & $\begin{array}{l}\text { Mx. Radial } \\
\text { Length } \\
\text { (MRL) }\end{array}$ & $\begin{array}{c}\text { Bi-iliac } \\
\text { Breadth } \\
\text { (BIB) }\end{array}$ & $\begin{array}{c}\text { Femoral } \\
\text { Head } \\
\text { Diameter } \\
\text { (FHD) }\end{array}$ & $\begin{array}{c}\text { Bicon- } \\
\text { dylar } \\
\text { Femoral } \\
\text { Length } \\
\text { (BFL) }\end{array}$ & $\begin{array}{c}\text { Mx. Tibial } \\
\text { Length (MTL) }\end{array}$ & $\begin{array}{l}\text { Brachial } \\
(* 100)^{\mathrm{a}}\end{array}$ & $\begin{array}{c}\text { Crural } \\
(* 100)^{b}\end{array}$ \\
\hline & & & $\begin{array}{r}\text { Mean } \\
(\mathrm{SD})\end{array}$ & $\begin{array}{l}\text { Mean } \\
(\mathrm{SD})\end{array}$ & $\begin{array}{l}\text { Mean } \\
(\mathrm{SD})\end{array}$ & Mean (SD) & $\begin{array}{l}\text { Mean } \\
(\mathrm{SD})\end{array}$ & $\begin{array}{l}\text { Mean } \\
(\mathrm{SD})\end{array}$ & $\begin{array}{l}\text { Mean } \\
(\mathrm{SD})\end{array}$ & $\begin{array}{l}\text { Mean } \\
(\mathrm{SD})\end{array}$ \\
\hline \multirow{3}{*}{ Terrestrial } & Male & 12 & $\begin{array}{l}314.56 \\
(6.89)\end{array}$ & $\begin{array}{l}253.50 \\
(11.56)\end{array}$ & $\underset{(8.52)}{292.00 *}$ & $\begin{array}{l}\text { 48.60* } \\
(2.74)\end{array}$ & $\begin{array}{l}\mathbf{4 5 8 . 8 8}^{*} \\
(22.15)\end{array}$ & $384.63(15.62)$ & $\begin{array}{l}80.56 \\
(4.51)\end{array}$ & $\begin{array}{l}84.21 \\
(1.64)\end{array}$ \\
\hline & Female & 1 & $\begin{array}{c}286.00 \\
\text { (n.a.) }\end{array}$ & 233.00 (n.a.) & n.a & n.a & n.a & $\begin{array}{l}330.00 \\
\text { (n.a) }\end{array}$ & $\begin{array}{l}81.46 \\
\text { (n.a) }\end{array}$ & n.a \\
\hline & Indet. & 1 & $\begin{array}{l}276.00 \\
\text { (n.a) }\end{array}$ & $\begin{array}{l}223.00 \\
\text { (n.a) }\end{array}$ & $\begin{array}{l}259.00 \\
\text { (n.a) }\end{array}$ & 40.14 (n.a) & $\begin{array}{l}392.50 \\
\text { (n.a) }\end{array}$ & $\begin{array}{l}328.00 \\
\text { (n.a) }\end{array}$ & $\begin{array}{c}80.80 \\
\text { (n.a) }\end{array}$ & $\begin{array}{r}83.57 \\
\text { (n.a) }\end{array}$ \\
\hline \multirow{3}{*}{ Marine } & Male & 19 & $\begin{array}{l}303.40 \\
(18.91)\end{array}$ & $\begin{array}{l}240.44 \\
(17.27)\end{array}$ & $\begin{array}{l}268.74 \\
(16.77)\end{array}$ & $\begin{array}{l}44.46 \\
(3.60)\end{array}$ & $\begin{array}{l}419.69 \\
(28.18)\end{array}$ & $354.32(23.64)$ & $\begin{array}{l}79.49 \\
(3.36)\end{array}$ & $\begin{array}{l}84.78 \\
(1.53)\end{array}$ \\
\hline & Female & 10 & $\begin{array}{l}283.69 \\
(11.40)\end{array}$ & $\begin{array}{l}215.97 \\
(13.22)\end{array}$ & $\begin{array}{l}258.36 \\
(10.27)\end{array}$ & $\begin{array}{l}39.41 \\
(2.19)\end{array}$ & $\begin{array}{l}379.53 \\
(16.07)\end{array}$ & $314.06(16.57)$ & $\begin{array}{l}76.01 \\
(2.12)\end{array}$ & $\begin{array}{l}82.27 \\
(2.41)\end{array}$ \\
\hline & Indet. & 1 & $\begin{array}{l}296.50 \\
\text { (n.a) }\end{array}$ & n.a & $\begin{array}{l}257.00 \\
\text { (n.a) }\end{array}$ & 36.69 (n.a) & $\begin{array}{l}398.00 \\
\text { (n.a) }\end{array}$ & $\begin{array}{c}373.50 \\
\text { (n.a) }\end{array}$ & n.a & $\begin{array}{l}93.84 \\
\text { (n.a) }\end{array}$ \\
\hline \multirow{3}{*}{$\begin{array}{l}\text { Mixed- } \\
\text { Economy }\end{array}$} & Male & 4 & $\begin{array}{l}316.83 \\
(17.74)\end{array}$ & $\begin{array}{l}239.25 \\
(28.64)\end{array}$ & 302 (n.a) & $\begin{array}{l}45.40 \\
(3.82)\end{array}$ & $\begin{array}{l}423.00 \\
(20.37)\end{array}$ & $360.00(21.07)$ & $\begin{array}{l}77.77 \\
(7.08)\end{array}$ & $\begin{array}{l}85.13 \\
(3.79)\end{array}$ \\
\hline & Female & 3 & $\begin{array}{l}302.25 \\
(4.60)\end{array}$ & $\begin{array}{l}\text { 237.25* } \\
(3.18)\end{array}$ & $\begin{array}{l}293.50 \\
(7.78)\end{array}$ & $\begin{array}{l}42.48 \\
(0.95)\end{array}$ & $\begin{array}{l}\text { 418.00* } \\
(12.82)\end{array}$ & $\begin{array}{l}347.67 * \\
(10.10)\end{array}$ & $\begin{array}{l}\text { 78.50* } \\
(0.14)\end{array}$ & $\begin{array}{l}83.19 \\
(1.52)\end{array}$ \\
\hline & Indet. & 0 & n.a & n.a & n.a & n.a & n.a & n.a & n.a & n.a \\
\hline
\end{tabular}

${ }^{\mathrm{a} B r a c h i a l}$ Index $=($ Maximun length of the radius/ Maximum length of the humerus $) * 100 ;{ }^{\mathrm{b}} \mathrm{Crural}$ Index $=($ Maximum length of the tibia/Bicondylar length of the femur) *100; $\mathrm{SD}=$ standard deviation; $\mathrm{n} . \mathrm{a} .=$ Not available; *= significant statistical difference at $\mathrm{p}<.05$; indet. $=$ indeterminate.

Only one female individual was identified among terrestrial hunter gatherers. Thus, comparisons between the groups were limited. Females from the mixedeconomy group had the largest dimensions, whether the dimensions were observable in all three groups or only among mixed-economy and marine females. Overall, the dimensions observed in the only available terrestrial female fell between those of mixed-economy and marine groups. Thus, marine females, like marine males, showed the shortest dimensions for the skeletal elements analyzed in this study (Table 1). Between groups comparisons were limited to female individuals assigned to the marine or the mixed-economy groups. Among females, comparisons of MHL showed no statistically significant difference between the groups ( $\mathrm{Z}=-1.89$, $\mathrm{p}>$.05), but comparisons of MRL were significant, confirming that this dimension was significantly shorter in marine females $(Z=-2.09$, $\mathrm{p}<.05$ ). Comparisons of the dimensions of the lower limb showed significant differences for BFL ( $\mathrm{Z}=-2.37$, $\mathrm{p}<.05)$, and MTL $(\mathrm{Z}=-2.13, \mathrm{p}<.05)$, where mixedeconomy female individuals had larger dimensions for these skeletal elements than marine female individuals. However, comparisons for the FHD ( $\mathrm{Z}=-1.72, \mathrm{p}>.05)$ and BIB $(Z=-2.06, p>.05=)$ were not significant.

Among males, results for the brachial index, the ratio between the radius and the humerus, showed to be slightly higher among terrestrial individuals, followed by marine and mixed-economy ones. Statistical comparisons between males from the three economic groups were not significantly different $\left(X^{2}=1.01, p>.05\right)$. The crural index, the ratio between the tibia and the femur, was similar in all groups (Table 1), but it showed to be slightly higher among mixed-economy males (Table 2), followed by marine, and terrestrial males. Between group comparisons of the crural index among males were not statistically significant $\left(X^{2}=.46 \mathrm{p}>.05\right)$. Among females, brachial index comparisons were statistically significant $(\mathrm{Z}=-2.09, \mathrm{p}<.05)$, due to mixed-economy females having a larger index than marine ones, although the highest value was identified in terrestrial females. But, since there is only one terrestrial female in this study, the comparisons are hindered. No significant difference was identified in the crural index of females $(\mathrm{Z}=-.65, \mathrm{p}>$.05).

Crural index comparisons between the sample analyzed in this study, and those published for other regions of North and South America are presented in Table 2. These comparisons showed that, when males and females are considered together, individuals from Fuego-Patagonia had a crural index that was most similar to that of the Temperate North American groups (Auerbach and Ruff 2010). Thus, the stature estimation formulae for Temperate groups (Auerbach and Ruff 2010) were applied in this study. Additionally, the formulae developed by Béguelin (2011) were also applied, to both male and 
Table 2. Crural Index comparisons between the sample and other groups for which stature formulae have been developed.

Comparación del índice crural de la muestra y el de otras poblaciones para las cuales se han desarrollado fórmulas para el cálculo de estatura.

\begin{tabular}{|c|c|c|c|c|c|}
\hline Sex & Sample & Mean & SD & Range & $\begin{array}{l}\text { Crural Index Listed Group } \\
\text {-Crural Index this Study }\end{array}$ \\
\hline \multirow{5}{*}{ Females } & Artic $^{\mathrm{a}}$ & 81.41 & 2.15 & $75.97-87.41$ & -1.09 \\
\hline & Temperate $^{\mathrm{a}}$ & 84.24 & 1.99 & $79.11-88.58$ & 1.74 \\
\hline & $\begin{array}{c}\text { Great } \\
\text { Plains }^{\mathrm{a}}\end{array}$ & 85.51 & 2.31 & $\begin{array}{c}80.576- \\
90.74\end{array}$ & 3.01 \\
\hline & Andean $^{\mathrm{b}}$ & 85.56 & 1.82 & $80.85-90.60$ & 3.06 \\
\hline & This Study & 82.50 & 2.19 & $78.91-85.60$ & \\
\hline \multirow{5}{*}{ Males } & Artic & 81.8 & 2.31 & $75.69-87.13$ & -2.92 \\
\hline & Temperate & 85.06 & 1.93 & $79.78-89.78$ & 0.34 \\
\hline & Great Plains & 85.67 & 2.17 & $79.32-90.77$ & 0.95 \\
\hline & Andean & 86.31 & 1.98 & $81.14-91.47$ & 1.59 \\
\hline & This Study & 84.72 & 1.85 & $81.90-89.31$ & \\
\hline
\end{tabular}

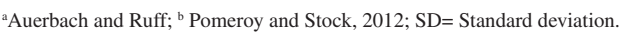

female individuals, given the geographic proximity and likely genetic relationship between these FuegoPatagonian populations on the Chilean side and those from the Argentine Patagonia.

Results for the stature estimates are presented in Table 3. Calculated statures consistently showed that terrestrial males were the tallest and marine males were the shortest. Males of mixed-economy have intermediate values in relation to these two groups (Table 3). Overall, terrestrial males are almost $10 \mathrm{~cm}$ taller (range of difference: 9.95$6.26 \mathrm{~cm}$ ) than males from the other two economic groups. This difference would have been easy to perceive during their lives.

Stature estimates consistently showed mixedeconomy females to be taller than marine ones (range of difference: $10.28-8.50 \mathrm{~cm}$; Table 3). This difference in stature would have been easily identified by any observer. The only stature estimate available for the one terrestrial female (based on the tibia; Table 3) showed this individual's height to be intermediate in comparison to the other two groups. But, given that there was only one terrestrial female in this sample, broader assessments were hindered.

Results for the estimation of body mass based on the biomechanical and morphometric methods are presented in Table 4. Among males, body mass estimates based on both the biomechanical and morphometric methods

Table 3. Descriptive Statistics for Stature Estimations (cm).

Resultados descriptivos para las estimaciones de estatura $(\mathrm{cm})$.

\begin{tabular}{|c|c|c|c|c|c|c|c|c|c|c|c|c|c|}
\hline \multirow{4}{*}{ 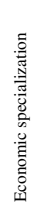 } & \multirow{4}{*}{ Sex } & \multicolumn{12}{|c|}{ Stature } \\
\hline & & \multicolumn{6}{|c|}{ Auerbach and Ruff (2010) } & \multicolumn{6}{|c|}{ Beguelin (2011) } \\
\hline & & \multicolumn{2}{|c|}{ Femur } & \multicolumn{2}{|c|}{ Tibia } & \multicolumn{2}{|c|}{ Femur+Tibia } & \multicolumn{2}{|c|}{ Femur } & \multicolumn{2}{|c|}{ Tibia } & \multicolumn{2}{|c|}{ Femur+Tibia } \\
\hline & & $\begin{array}{l}\text { Mean } \\
\text { (SD) }\end{array}$ & Range & $\begin{array}{l}\text { Mean } \\
\text { (SD) }\end{array}$ & Range & $\begin{array}{l}\text { Mean } \\
(\mathrm{SD})\end{array}$ & Range & $\begin{array}{l}\text { Mean } \\
\text { (SD) }\end{array}$ & Range & $\begin{array}{c}\text { Mean } \\
\text { (SD) }\end{array}$ & Range & $\begin{array}{l}\text { Mean } \\
\text { (SD) }\end{array}$ & Range \\
\hline \multirow{3}{*}{ 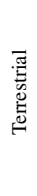 } & Male & $\begin{array}{l}169.40 \\
(5.63)\end{array}$ & $\begin{array}{r}162.45- \\
180.87\end{array}$ & $\begin{array}{l}167.82 \\
(4.72)\end{array}$ & $\begin{array}{l}160.83- \\
170.95\end{array}$ & $\begin{array}{l}168.63 \\
(3.77)\end{array}$ & $\begin{array}{l}162.98- \\
170.68\end{array}$ & $\begin{array}{l}170.79 \\
(4.90)\end{array}$ & $\begin{array}{l}164.74- \\
180.76\end{array}$ & $\begin{array}{l}169.30 \\
(3.97)\end{array}$ & $\begin{array}{l}163.42- \\
171.93\end{array}$ & 170.11 & $\begin{array}{l}165.08- \\
171.89\end{array}$ \\
\hline & Female & n.a & n.a & $\begin{array}{l}149.98 \\
\text { (n.a) }\end{array}$ & n.a & n.a & n.a & n.a & n.a & $\begin{array}{c}155.42 \\
\text { (n.a) }\end{array}$ & n.a & n.a & n.a \\
\hline & Indet. & n.a & n.a & n.a & n.a & n.a & n.a & $\begin{array}{c}156.12 \\
\text { (n.a) }\end{array}$ & n.a & $\begin{array}{c}154.91 \\
\text { (n.a) }\end{array}$ & n.a & $\begin{array}{c}155.01 \\
\text { (n.a) }\end{array}$ & n.a \\
\hline \multirow{3}{*}{ 营 } & Male & $\begin{array}{l}159.45 \\
(7.16)\end{array}$ & $\begin{array}{c}149.75- \\
175.53\end{array}$ & $\begin{array}{l}158.67 \\
(7.14)\end{array}$ & $\begin{array}{l}148.30- \\
175.48\end{array}$ & $\begin{array}{l}159.30 \\
(6.76)\end{array}$ & $\begin{array}{l}149.96- \\
176.05\end{array}$ & $\begin{array}{l}162.13 \\
(6.23)\end{array}$ & $\begin{array}{l}153.69- \\
176.12\end{array}$ & $\begin{array}{l}161.60 \\
(6.01)\end{array}$ & $\begin{array}{l}152.88- \\
175.74\end{array}$ & $\begin{array}{l}161.47 \\
(6.08)\end{array}$ & $\begin{array}{l}153.58- \\
176.58\end{array}$ \\
\hline & Female & $\begin{array}{l}146.13 \\
(4.29)\end{array}$ & $\begin{array}{c}140.92- \\
154.54\end{array}$ & $\begin{array}{l}145.26 \\
(4.90)\end{array}$ & $\begin{array}{c}139.92- \\
152.64\end{array}$ & $\begin{array}{l}145.67 \\
(4.46)\end{array}$ & $\begin{array}{l}140.27- \\
153.52\end{array}$ & $\begin{array}{l}153.26 \\
(3.55)\end{array}$ & $\begin{array}{l}148.94- \\
160.21\end{array}$ & $\begin{array}{l}151.37 \\
(4.21)\end{array}$ & $\begin{array}{l}146.78- \\
157.71\end{array}$ & $\begin{array}{l}151.92 \\
(3.83)\end{array}$ & $\begin{array}{l}147.32- \\
158.45\end{array}$ \\
\hline & Indet. & n.a & n.a & n.a & n.a & n.a & n.a & $\begin{array}{c}157.39 \\
\text { (n.a) }\end{array}$ & n.a & $\begin{array}{c}166.47 \\
\text { (n.a) }\end{array}$ & n.a & $\begin{array}{c}161.39 \\
\text { (n.a) }\end{array}$ & n.a \\
\hline \multirow{3}{*}{ 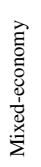 } & Male & $\begin{array}{l}160.29 \\
(5.17)\end{array}$ & $\begin{array}{c}154.83- \\
165.12\end{array}$ & $\begin{array}{l}160.38 \\
(6.36)\end{array}$ & $\begin{array}{c}153.74- \\
166.42\end{array}$ & $\begin{array}{l}160.15 \\
(5.38)\end{array}$ & $\begin{array}{l}153.94- \\
163.44\end{array}$ & $\begin{array}{l}162.86 \\
(4.50)\end{array}$ & $\begin{array}{l}158.11- \\
167.06\end{array}$ & $\begin{array}{l}163.04 \\
(5.35)\end{array}$ & $\begin{array}{l}157.45- \\
168.12\end{array}$ & $\begin{array}{l}162.83 \\
(4.71)\end{array}$ & $\begin{array}{l}157.39- \\
165.64\end{array}$ \\
\hline & Female & $\begin{array}{l}156.41 \\
(3.42)\end{array}$ & $\begin{array}{c}153.20- \\
160.01\end{array}$ & $\begin{array}{l}155.21 \\
(2.99)\end{array}$ & $\begin{array}{c}151.76- \\
156.94\end{array}$ & $\begin{array}{l}156.00 \\
(3.29)\end{array}$ & $\begin{array}{c}152.52- \\
159.05\end{array}$ & $\begin{array}{l}161.76 \\
(2.83)\end{array}$ & $\begin{array}{c}159.11- \\
164.74\end{array}$ & $\begin{array}{l}159.91 \\
(2.57)\end{array}$ & $\begin{array}{l}156.94- \\
161.39\end{array}$ & $\begin{array}{l}160.66 \\
(2.73)\end{array}$ & $\begin{array}{c}157.70- \\
163.08\end{array}$ \\
\hline & Indet. & $\mathrm{n} . \mathrm{a}$ & n.a & n.a & $\mathrm{n} . \mathrm{a}$ & n.a & n.a & n.a & n.a & n.a & n.a & n.a & n.a \\
\hline
\end{tabular}


showed to be consistently higher among terrestrial individuals, while marine males had the lowest values. Comparisons of the results obtained with the biomechanical method revealed a statistically significant difference between the groups $\left(\mathrm{X}^{2}=6.54, \mathrm{p}<.05\right)$. Posthoc comparisons indicate that terrestrialor males had a significantly larger body mass than marine ones $(\mathrm{Z}=-$ $2.50, \mathrm{p}<.05)$. No other statistically significant difference was identified among males. Estimates of body mass based on the morphometric method were also significant $\left(\mathrm{X}^{2}=6.51, \mathrm{p}<.05\right)$. Post-hoc analyses showed significant differences between terrestrial and marine males $(\mathrm{Z}=-$ $2.24, \mathrm{p}<.05)$. No other statistically significant differences among males were found. Body mass index for males showed a slightly higher average for terrestrial males, followed by mixed-economy and marine males (Table 4). However the results are similar and statistical comparisons revealed no significant differences $\left(\mathrm{X}^{2}=2.92, \mathrm{p}>.05\right)$.

Body mass estimates showed mixed-economy females to have a larger body mass than marine ones (Table 4). No estimates are available for terrestrial females. Comparisons of body mass between marine and mixed-economy females, were not statistically significant, when estimated with the biomechanical method $(\mathrm{Z}=-$ $1.72 ; \mathrm{p}>.05)$. But, comparisons with the morphometric method showed body mass to be significantly higher among mixed-economy females $(\mathrm{Z}=-2.05, \mathrm{p}<.05)$. BMI

Table 4. Descriptive Statistics for Body Mass (kg) estimates and Body Mass Index.

Resultados descriptivos para las estimaciones de masa $(\mathrm{kg})$ e índice de masa.

\begin{tabular}{|c|c|c|c|c|c|c|c|}
\hline \multirow{3}{*}{$\begin{array}{c}\text { Economic } \\
\text { Specialization }\end{array}$} & \multirow{3}{*}{ Sex } & \multicolumn{4}{|c|}{ Body Mass } & \multicolumn{2}{|c|}{$\begin{array}{l}\text { Body Mass } \\
\text { Index }^{c}\end{array}$} \\
\hline & & \multicolumn{2}{|c|}{ Biomechanical $^{a}$} & \multicolumn{2}{|c|}{ Morphometric ${ }^{b}$} & \multirow[b]{2}{*}{$\begin{array}{l}\text { Mean } \\
\text { (SD) }\end{array}$} & \multirow[b]{2}{*}{ Range } \\
\hline & & $\begin{array}{l}\text { Mean } \\
(\mathrm{SD})\end{array}$ & Range & $\begin{array}{c}\text { Mean } \\
(\mathrm{SD})\end{array}$ & Range & & \\
\hline \multirow{3}{*}{ Terrestrial } & Male & $\begin{array}{l}71.04 * \\
(6.37)\end{array}$ & $\begin{array}{l}64.79- \\
81.07\end{array}$ & $\begin{array}{l}77.19 * \\
(1.29)\end{array}$ & $\begin{array}{l}75.78- \\
78.31\end{array}$ & $\begin{array}{l}25.50 \\
(1.40)\end{array}$ & $\begin{array}{l}24.12 \\
27.62\end{array}$ \\
\hline & Female & n.a & $\mathrm{n} \cdot \mathrm{a}$ & n.a & $\mathrm{n} \cdot \mathrm{a}$ & n.a & n.a \\
\hline & Indet. & $\begin{array}{c}52.26 \\
\text { (n.a) }\end{array}$ & n.a & n.a & n.a & n.a & n.a \\
\hline \multirow{3}{*}{ Marine } & Male & $\begin{array}{l}61.42 \\
(8.36)\end{array}$ & $\begin{array}{l}49.92- \\
74.53\end{array}$ & $\begin{array}{l}64.01 \\
(8.05)\end{array}$ & $\begin{array}{l}51.81- \\
82.96\end{array}$ & $\begin{array}{l}24.15 \\
(1.37)\end{array}$ & $\begin{array}{l}21.74 \\
26.46\end{array}$ \\
\hline & Female & $\begin{array}{l}51.90 \\
(4.89)\end{array}$ & $\begin{array}{l}42.97- \\
58.87\end{array}$ & $\begin{array}{l}51.23 \\
(3.87)\end{array}$ & $\begin{array}{l}46.66- \\
58.50\end{array}$ & $\begin{array}{l}23.30 \\
(1.51)\end{array}$ & $\begin{array}{l}20.46 \\
25.27\end{array}$ \\
\hline & Indet. & $\begin{array}{l}44.48 \\
\text { (n.a) }\end{array}$ & n.a & n.a & n.a & n.a & n.a \\
\hline \multirow{3}{*}{ Mixed-Economy } & Male & $\begin{array}{l}63.60 \\
(8.87)\end{array}$ & $\begin{array}{l}55.88- \\
73.30\end{array}$ & $\begin{array}{l}76.96 \\
\text { (n.a) }\end{array}$ & n.a & $\begin{array}{c}25.24 \\
(2.1)\end{array}$ & $\begin{array}{l}22.99 \\
27.16\end{array}$ \\
\hline & Female & $\begin{array}{l}58.72 \\
(2.13)\end{array}$ & $\begin{array}{l}57.22- \\
60.23\end{array}$ & $\begin{array}{r}\mathbf{6 4 . 6 5}^{*} \\
(2.37)\end{array}$ & $\begin{array}{l}62.97- \\
66.33\end{array}$ & $\begin{array}{c}24.14 \\
(.37)\end{array}$ & $\begin{array}{r}23.87 \\
24.40\end{array}$ \\
\hline & Indet. & n.a & n.a & n.a & n.a & n.a & n.a \\
\hline
\end{tabular}

$\mathrm{a}=$ Standard deviation in parenthesis; $\mathrm{b}=$ Average calculated based on the result obtained with the formulae published by Ruff et al. 1991; McHenry 1992; Grine et al. 1995; c= Based on formulae published by Auerbach and Ruff (2004); SD= Standard deviation; n.a.= not available; $*=$ significant statistical difference at $\mathrm{p}<.05$. estimates were higher for mixed economy females (Table 4). However, statistical comparisons did not reveal significant differences between these two groups $(Z=-.47$, $\mathrm{p}>.05)$.

\section{Discussion}

The results obtained suggest an East to West phenotypic gradient, where males and females from the eastern side and belonging to the terrestrial huntergatherer groups, tended to be taller than those to the West, of mixed or marine economy. Moreover, while mixed-economy individuals showed, for the most part, intermediate dimensions, indices and height, marine individuals were the smallest and lightest ones. Although not all between-group comparisons were statistically significant, assessment of the length of the lower limb (femur and tibia) tended to be significant in most comparisons for males. Females showed a similar trend, but the limited number of terrestrial females hindered most comparisons. Nevertheless, BFL and MTL were significantly longer in mixed economy females in relation to marine ones. Both dimensions contribute directly to the stature of these individuals.

Analyses of body mass showed the same trend. Terrestrial males were the heaviest, marine ones were the lightest, and mixed-economy individuals presented an intermediate body mass. Females show a similar trend, with mixed economy females being heavier than marine ones. Based on body mass index estimations (BMI), the differences in body mass respond to differences in stature. For the most part individuals in all groups were relatively heavy, specially terrestrial and mixed-economy males, whose BMI was close or above the healthy range for modern groups (BMI>25). Among females, the BMI showed to be within the healthy range (BMI 20-25), but it was close to its upper end. The results are in agreement with the high BMI reported in ethnographic accounts (Gusinde 1980). A high BMI could be an adaptation to the cold temperatures of the region.

Among males, comparisons of body proportions through the brachial and crural indexes showed no statistically significant differences between the groups. Among females, only the brachial index showed a significant difference between mixed economy and marine females. Other studies have shown that the crural index does respond in part to latitude, but that radial length variation is not accounted for latitude to the degree that other body segment's lengths and proportions are (Roseman and Auerbach 2015). The absence of significant differences in the crural indexes for both males and females, indicate that although differences in stature were significant, they were not due to differences in leg proportions. This pattern then may be the result of differences in short term adaptive responses, where developmental plasticity would have led individuals from these groups into different growth outcomes. Thus, this 
seems to be a response to differences in environment, that have not occurred over a time span that is long enough to lead to evolutionary changes (Ruff 1994, 2002). That is an scenario that fits well with the timeline for the human colonization of the region.

Beyond statistical significance we must look into biological and cultural relevance. The results obtained suggest that the observations made by explorers and ethnographers were correct and indicated the existence of an East-West phenotype gradient in the region. While in the occidental archipelago, marine groups were shorter and lighter, the terrestrial hunter-gatherers of the eastern pampas of Southern Patagonia and Tierra del Fuego were consistently larger and heavier. The differences in weigh however, respond to differences in stature, as overall body mass index tends to be high in all these groups. High body mass was one of the observations made by Gusinde (1980) in historic times, and it maybe indicative of an adaptation to the cold temperatures that characterize the entire region. Moreover, BIB high values $(>24 \mathrm{~cm})$ were observed in all the groups, and are characteristic of high latitude populations (Ruff 1994). Previous studies have also identified evidence of cold adaptation in Fuego-Patagonia groups (Bernal et al 2006; Pearson and Millones 2005). Although the differences in temperature between the areas West and East to the Andes are small, the differences in humidity are noticeable (Pisano 1977). This is important, as humidity does affect thermal comfort, and temperature dissipation. Higher humidity, and closed environments, like the ones west of the Andes in Fuego-Patagonia, are associated with shorter stature, whereas open environments with low humidity, like the steppes and pampas East of the Andes, are associated with taller individuals (Ruff 1994). Thus, the marked differences in humidity between these two regions (west and east of the Andes) could explained the differences in stature observed in this study.

The differences in phenotype found in this study can be interpreted as adaptations to a cold and harsh environment, but these likely have some genetic basis, given that an individual's genome limits the possible responses to environmental stimuli (Charnov 1993; Metcalfe and Monaghan 2001). Thus, some of these differences may be the end product of adaptations to environments that present significant differences in thermal sensation, humidity, vegetation assemblages and landscape conformation. If these differences reflect some degree of genetic distance, this would support the idea that marine populations, present in FuegoPatagonia since ca. 7,000 cal yrs. BP, arrived into the area as the result of a migration that followed the Pacific coast from north to south, thus representing a second migration wave into the region. If correct, it is likely that genetic and phenotypic differences between marine and terrestrial groups were somewhat maintained by geographic barriers such as the Southern Ice Field and the Magellan Strait, among others (Figure 1). However, differences in height between the groups could also be explained by differences in diet and overall health (Bogin 1999, 2001; Eveleth and Tanner 1991; Lee et al. 2014; Lejarraga 2002; Pomeroy et al. 2012, 2015; Tanner 1990; Ulijaszek et al. 1998). And in fact, it is important to keep in mind, that these marked environmental and landscape variations have been matched to contrasting lifestyles, social conditions, terrains and ranging behaviors between terrestrial and marine hunter-gatherer groups in Fuego-Patagonia. All of these factors are relevant as they can affect body size (Hermanussen et al. 2015; Higgins and Ruff 2011). Therefore, whether these differences can be explained by environmental, cultural, and/or genetic factors needs further exploration and more studies that attempt to characterize the diet and health of these groups. Moreover, this study is limited due to the small sample size. Thus, future studies that expand on this sample will allow us to explore this phenotypic gradient with higher confidence.

\section{Conclusions}

The phenotypic differences identified in this study, between terrestrial and marine hunter-gatherers of Fuego-Patagonia, suggest that marine and terrestrial individuals where somewhat phenotypically distinct, at least in terms of their stature and weight, but not in their limb proportions or body mass. It is certainly interesting that mixed-economy individuals showed an intermediate height and weight, which could reflect their adaptation to a mixed economy way of life, an intermediate territory, and/or the genetic contributions from both marine and terrestrial groups. The results suggest that there were phenotypic differences between the groups, which would have been documented by European observers, which supports, in part, Hypothesis 2. Given the vast differences in humidity, it is likely that this environmental factor accounts for the differences observed in stature. Humidity could have acted as a selective force for lower stature in the west, and higher stature in the east. However, more paleopathological, dietary, and genetic studies in this region are needed if we are to fully understand the biological variability of the Fuego-Patagonian groups. The results of this study, although suggestive, are based on a small sample size, and thus the conclusions are limited and require more exploration. Therefore, future studies should endeavor to enlarge the sample and further explore these differences and their implications.

Acknowledgments: We would like to thank the Centro de Estudios del Hombre Austral, Instituto de la Patagonia, Universidad de Magallanes, for granting us access to the material. We also like to thank the Editor, Dr. Vivien Standen, and three anonymous reviewers for their insightful comments. This study was funded by FONDECYT grant 1140939. 


\section{References Cited}

Acsádi, G. and J. Nemeskéri 1979. History of Human Lifespan. Akadémiai Kiadó, Budapest.

Alfonso-Durruty, M.P., B. Giles, N. Misarti, M. San Román, and F. Morello 2015. Antiquity and geographic distribution of cranial modification among the prehistoric groups of Fuego-Patagonia, Chile. American Journal of Physical Anthropology 158:607-623.

Allen, J.A. 1877. The influence of physical conditions in the genesis of species. Radical Review 1:107-140.

Angel, A.D. and H.B. Cisneros 2004. Technical note: Modification of regression equations used to estimate stature in mesoamerican skeletal remains. American Journal of Physical Anthropology 125:264-265.

Auerbach, B.M. 2012. Skeletal variation among early Holocene North American humans: Implications for origins and diversity in the Americas. American Journal of Physical Anthropology 149:525-536.

Auerbach, B.M. 2014. Goldman Osteometric Data Set. Goldman Osteometric Data Set. https://web.utk.edu/ auerbach/GOLD.htm, accessed June 10, 2015.

Auerbach, B.M. and C.B. Ruff 2004. Human body mass estimation: A comparison of "morphometric" and "mechanical" methods. American Journal of Physical Anthropology 125:331-342.

Auerbach, B.M. and C.B. Ruff 2006. Limb bone bilateral asymmetry: Variability and commonality among modern humans. Journal of Human Evolution 50:203-218.

Auerbach, B.M. and C.B. Ruff 2010. Stature estimation formulae for Indigenous North American populations. American Journal of Physical Anthropology 141:190-207.

Béguelin, M. 2011. Stature estimation in a Central Patagonian prehispanic population: Development of new models considering specific body proportions. International Journal of Osteoarchaeology 21:150-158.

Béguelin, M. and G. Barrientos 2006. Variacion morfométrica postcraneal en muestras tardías de restos humanos de Patagonia: Una aproximacion biogeografica. Intersecciones en Antropología 7:49-62.

Bergmann, C. 1847. Uber Die Verhältnisse Der Warmeokonomie Der Thiere Zu Ihrer Grösse. Göttingen Studien 1:595-708.

Bernal, V., S.I. Perez, and P.N. González 2006. Variation and causal factors of craniofacial robusticity in Patagonian hunter-gatherers from the Late Holocene. American Journal of Human Biology 18:748-765.

Betti, L., N. Von Cramon-Taubadel, and S.J. Lycett 2012. Human pelvis and long bones reveal differential preservation of ancient population history and migration out of Africa. Human Biology 84:139-152.

Bird, J. 1946. South American Indians. In Handbook of South American Indians, edited by J.H. Steward, pp. 17-24. Bureau of American Ethnology Bulletin, 143. Smithsonian Institution, Washington DC.

Bird, J. 1993. Viajes y Arqueología de Chile Austral. Universidad de Magallanes, Punta Arenas.

Bogin, B. 1999. Patterns of Human Growth. $2^{\text {nd }}$ edition. Cambridge University Press, Cambridge.

Bogin, B. 2001. The Growth of Humanity. $1^{\text {st }}$ edition. Wiley-Liss, New York.

Borrero, L. 2002. The archaeology of Patagonia. In Archaeological and Anthropological Perspectives on the Native Peoples of Pampa,
Patagonia, and Tierra del Fuego to the Nineteenth Century, edited by C. Briones and J.L. Lanata, pp. 47-55. Bergin \& Garvey Westport, Connecticut.

Borrero, L.A. 1989. Evolución cultural divergente en la Patagonia Austral. Anales del Instituto de la Patagonia, Serie Ciencias Humanas 19:133-140.

Borrero, L.A. 1999. The prehistoric exploration and colonization of Fuego-Patagonia. Journal of World Prehistory 13:321-355.

Borrero, L.A. and F.M. Martin 2012. Ground sloths and humans in southern Fuego-Patagonia: Taphonomy and archaeology. World Archaeology 44:102-117.

Borrero, L.A., F.M. Martin, and R. Barbarena 2011. Visit, "Fuegians", and information networks. In Information and its Role in HunterGatherer Bands, edited by R.Whallon, W. Lovis, and R. Hitchcock, pp. 249-265. Ideas, Debates and Perspectives, 5. Cotsen Institute of Archaeology Press, Los Angeles.

Brooks, S.T. and J.M. Suchey 1990. Skeletal age determination based on the os pubis: A comparison of the Acsádi-Nemeskéri and SucheyBrooks Methods. Human Evolution 5:227-238.

Buikstra, J.E. and D.H. Ubelaker 1994. Standards for Data Collection from Human Skeletal Remains: Proceedings of a Seminar at the Field Museum of Natural History. Arkansas Archeological Survey, Arkansas.

Charnov, E.L. 1993. Life History Invariants. Oxford University Press, Oxford, UK.

Davenport, C.B. 1933. The crural index. American Journal of Physical Anthropology 17:333-353.

Emperaire, J. 2002. Los Nómades del Mar. Ediciones Lom, Santiago.

Eveleth, P.B. and J.M. Tanner 1991. Worldwide Variation in Human Growth. 2 edition. Cambridge University Press, Cambridge UK.

Frisancho, A.R. 2007. Relative leg length as a biological marker to trace the developmental history of individuals and populations: Growth delay and increased body fat. American Journal of Human Biology 19:703710.

Grine, F.E., W.L. Jungers, P.V. Tobias, and O.M. Pearson 1995. Fossil Homo femur from Berg Aukas, northern Namibia. American Journal of Physical Anthropology 97:151-185.

Gusinde, M. 1961. The Yamana. The Life and Thought of the Water Nomads of Cape Horn. Human Relations Area Files, New Haven, Connecticut.

Gusinde, M.1980. Los Indios de Tierra del Fuego - Tomo 4 Antropología Física, vol. 1. 2nd edition. Zagier \& Urruty Pubns, Centro Argentino de Etnología Americana, Buenos Aires.

Gusinde, M. 1982. The Selk'nam. On the Life and Thought of a Hunting People on the Great Island of Tierra del Fuego. Human Relations Area Files, New Haven, Connecticut.

Hermanussen, M., C. Scheffler, D. Groth, and C. Aßmann 2015. Height and skeletal morphology in relation to modern life style. Journal of Physiological Anthropology 34:41.

Higgins, R.W. and C.B. Ruff 2011. The effects of distal limb segment shortening on locomotor efficiency in sloped terrain: Implications for Neandertal locomotor behavior. American Journal of Physical Anthropology 146:336-345.

Holliday, T.W. 1997. Body proportions in Late Pleistocene Europe and modern human origins. Journal of Human Evolution 32: 423-448. 
Holliday, T.W. and A.B. Falsetti. 1995. Lower limb length of European Early Modern Humans in relation to mobility and climate. Journal of Human Evolution 29:141-153.

Holliday, T.W. and C.E. Hilton 2010. Body proportions of circumpolar peoples as evidenced from skeletal data: Ipiutak and Tigara (Point Hope) versus Kodiak Island Inuit. American Journal of Physical Anthropology 142:287-302.

IBM Corp. 2012. IBM SPSS Statistics for Windows, Version 21.0. Armon, NY: IBM Corp.

Katz, D. and J.M. Suchey 1986. Age determination of the male os pubis. American Journal of Physical Anthropology 69:427-435.

Laming-Emperaire, A., D. Lavallée, and R. Humber 1972. Le site de Marazzi en Terre de Fue. Objects et Mondes 12:225-244.

Lanata, J.L. 2002. The world's southernmost foragers: The native diversity of Tierra del Fuego. In Archaeological and Anthropological Perspective on the Native Peoples of Pampa, Patagonia, and Tierra del Fuego to the Nineteenth Century, edited by C. Briones and J.L. Lanata, pp. 57-73. Bergin \& Garvey, Westport, Connecticut.

Lee, S., V. Bountziouka, S. Lum, J. Stocks, R. Bonner, M. Naik, H. Fothergil, and J.C.K. Wells 2014. Ethnic variability in body size, proportions and composition in children aged 5 to 11 years: Is ethnicspecific calibration of bioelectrical impedance required? PloS One 9: e113883.

Legoupil, D. 2003. Cazadores-Recolectores de Ponsonby (Patagonia Austral) y su Paleoambiente desde el VI al III Milenio A.C. Magallania 31, Número Especial, Punta Arenas.

Lejarraga, H. 2002. Growth in infancy and childhood: A pediatric approach. In Human Growth and Development, edited by $\mathrm{N}$. Cameron, pp. 21-44. Academic Press, San Diego.

Livshits, G., A. Roset, K. Yakovenko, S. Trofimov, and E. Kobyliansky 2002. Genetics of human body size and shape: Body proportions and indices. Annals of Human Biology 29:271-289.

Lovejoy, C. Owen, R. Meindl, T.R. Pryzbeck, and R.P. Mensforth 1985. Chronological metamorphosis of the auricular surface of the ilium: A new method for the determination of age at death. American Journal of Physical Anthropology 68:15-28.

Martin, F.M., D. Todisco, J. Rodet, M. San Román, F. Morello, F. Prevosti, C. Stern, and L.A. Borrero 2015. Nuevas excavaciones en la Cueva del Medio. Resultados preliminares. Magallania 43:165-189.

Martinic, M. 1995. Los Aonikenk: Historia y Cultura. Ediciones de la Universidad de Magallanes, Punta Arenas.

Massone, M. 1989. Los cazadores de la Tierra Del Fuego, 8,000 a.C. al Presente. In Culturas de Chile. Desde sus Orígenes hasta los Albores de la Conquista, edited by J. Hidalgo, pp. 349-366. Editorial Andrés Bello, Santiago.

Massone, M. 2004. Los Cazadores después del Hielo. Museo de Historia Natural, Santiago.

Massone, M. and A. Prieto 2004. Evaluación de la Modalidad Cultural Fell 1 en Magallanes. Chungara Revista de Antropología Chilena 36, Vol especial tomo I, pp. 303-315.

Mayr, E. 1956. Geographical character gradients and climatic adaptation. Evolution 10:105-108.

McCulloch, R., M.J. Bentley, R.M. Tipping, and C. Clapperton 2005. Evidence for late-glacial ice dammed lakes in the central Strait of Magellan and Bahía Inútil, Southernmost South America. Geografiska Annaler 87A:335-362.
McHenry, H. 1992. Body size and proportions in early Hominids. American Journal of Physical Anthropology 87:407-431.

Meindl, R. and C.O. Lovejoy 1985. Ectocranial suture closure: A revised method for the determination of skeletal age at death based on the lateral-anterior sutures. American Journal of Physical Anthropology 68:57-66.

Meindl, R. 1989. Age changes in the pelvis: Implications for paleodemography. In Age Markers in the Human Skeleton, edited by M.Y. Iscan, pp. 137-168. Charles C. Thomas, Springfield.

Meinhardt, U., F. Witassek, R. Petrò, C. Fritz, and U. Eiholzer 2017. Less physically active children are shorter. Minerva Pediatrica 69:135-140.

Metcalfe, N.B., and P. Monaghan 2001. Compensation for a bad start: Grow now, pay later? Trends in Ecology \& Evolution 16:254-260.

Moore, D. 1983. Flora of Tierra del Fuego. Anthony Nelson, Ltd., Shropshire.

Morello, F., L. Borrero, M. Massone, C. Stern, A. García-Herbst, R. McCulloch, I. Martínez, G. Bahamondes, and P. Cárdenas 2012. Hunter-gatherers, biogregraphic barriers and the development of human settlement in Tierra del Fuego. Antiquity 86:71-87.

Norgan, N.G. 2002. Nutrition and growth. In Human Growth and Development, edited by N. Cameron, pp. 139-164. Academic Press, San Diego.

Orquera, L.A., D. Legoupil, and E.L. Piana 2011. Litoral adaptation at the southern end of South America. Quaternary International 239:6169.

Orquera, L.A. and E.L. Piana 1999. La Vida Material y Social de los Yámana. Eudeba, Buenos Aires.

Ortiz-Troncoso, O. 1975. Los yacimientos de Punta Santa Ana y Bahía Buena (Patagonia Austral). Excavaciones y fechados radiocarbónicos. Anales del Instituto de la Patagonia, Serie Ciencias Humanas 7:93122.

Pearson, O.M. and M. Millones 2005. Skeletal features showing adaptation to climate and activity of aboriginal inhabitants of Tierra del Fuego. Magallania 33:37-50.

Phenice, T. 1969. A newly developed visual method of sexing in the Os Pubis. American Journal of Physical Anthropology 30:297-301.

Pisano, E. 1977. Fitogeografía de Fuego-Patagonia Chilena. I.Comunidades vegetales entre las latitudes $52^{\circ}$ y $56^{\circ} \mathrm{S}$. Anales del Instituto de la Patagonia Serie Ciencias Humanas 8:121-250.

Pomeroy, E. and J.T. Stock 2012. Estimation of stature and body mass from the skeleton among coastal and mid-altitude Andean populations. American Journal of Physical Anthropology 147:264-279.

Pomeroy, E., J. T. Stock, S. Stanojevic, J.J. Miranda, T.J. Cole, and J.C.K. Wells 2012. Trade-offs in relative limb length among Peruvian children: Extending the thrifty phenotype hypothesis to limb proportions. PloS One 7:e51795.

Pomeroy, E., J.C.K. Wells, T.J. Cole, M. O'Callaghan, and J.T. Stock 2015. Relationships of maternal and paternal anthropometry with neonatal body size, proportions and adiposity in an Australian cohort. American Journal of Physical Anthropology 156:625-636.

Roseman, C.C. and B.M. Auerbach 2015. Ecogeography, genetics, and the evolution of human body form. Journal of Human Evolution 78:80-90.

Ruff, C.B. 2000. Body size, body shape, and long bone strength in modern humans. Journal of Human Evolution 38:269-290. 
Ruff, C.B., W.W. Scott, and A. Liu 1991. Articular and diaphyseal remodeling of the proximal femur with changes. American Journal of Physical Anthropology 86:397-413.

Ruff, C.B. 2002. Variation in human body size and shape. Annual Review of Anthropology 31:211-232.

Ruff, C.B. 1994. Morphological adaptation to climate in modern and fossil Hominids. American Journal of Physical Anthropology 37:65107.

Ruff, C.B., E. Trinkaus, and T.W. Holliday 1997. Body mass and encephalization in Pleistocene Homo. Nature 387:173-176.

Salemme, M., G. Bujalesky, and F. Santiago 2007. La Arcillosa 2: La ocupación humana durante el Holoceno Medio del Río Chico, Tierra Del Fuego, Chile. In Arqueología de Fuego-Patagonia. Levantando Piedras, Desenterrando Huesos, y Develando Arcanos. Sextas Jornadas de Arqueología de la Patagonia, pp. 723-736. Ediciones CEQUA, Punta Arenas.

San Román, M. 2014. Sea-level changes and coastal peopling in southernmost Pacific South America: Marine hunters from Patagonia. In Encyclopedia of Global Archaeology, edited by C. Smith, pp. 65156525. Springer, New York.

Schell, L.M. and K.L. Knutsen 2002. Environmental effects on growth. In Human Growth and Development, edited by N. Cameron, pp. 165-195. Academic Press, San Diego.

Schell, L.M. and P.D. Magnus 2007. Is there an elephant in the room? Addressing rival approaches to the interpretation of growth perturbations and small size. American Journal of Human Biology 19:606-614.

Specker, B.L. and E. Schoenau 2005. Quantitative bone analysis in children: Current methods and recommendations. The Journal of Pediatrics 146:726-731.

Stinson S. 2000. Growth variation: Biological and cultural factors. In Human Biology an Evolutionary and Biocultural Perspective, edited by S. Stinson, B. Bogin, R. Huss-Hashmore, and D. O'Rourke, pp. 425-463. Wiley-Liss. New York.

Tanner, J.M 1990. Fetus into Man: Physical Growth from Conception to Maturity. Revised edition. Harvad University Press, Cambridge.

Ulijaszek, S.J., F.E. Johnston, M.A. Preece, and J.M. Tanner 1998. The Cambridge Encyclopedia of Human Growth and Development. $1^{\text {st }}$ edition. Cambridge University Press, Cambridge.

White, T.D., M.T. Black, and P.A. Folkens 2012. Human Osteology. Elsevier/Academic Press, Amsterdam. 